\title{
Partisipasi Mahasiswa dalam Berorganisasi di Fakultas Ilmu Sosial Universitas Negeri Padang
}

\author{
Rizka Morina, Susi Fitria Dewi \\ Program Studi Pendidikan Pancasila dan Kewarganegaraan \\ Universitas Negeri Padang \\ E-mail: rizkamorina@gmail.com
}

\section{ABSTRAK}

Penelitian ini dilatarbelakangi karena rendahnya partisipasi mahasiswa dalam mengikuti organisasi di tingkat fakultas. Tujuan dari penelitian ini adalah mendeskripsikan bentuk-bentuk partisipasi, respon keterlibatan mahasiswa serta upaya meningkatkan partisipasi mahasiswa dalam berorganisasi di Fakultas Ilmu Sosial. Penelitian ini menggunakan metode kualitatifpendekatan deskriptif dengan informan penelitan terdiri dari Wakil Dekan III FIS UNP, Pembina organisasi mahasiswa, ketua BPM, Gubernur BEM, Ketua HMJ ISP, ketua HMJ Sosiologi, Ketua HMJ IAN, Ketua HMJ Sejarah, Ketua HMJ Geografi, Ketua HMJ Pendikais, dan mahasiswa Fakultas Ilmu Sosial. Metode pengumpulan data berupa observasi, wawancara dan dokumentasi. Hasil penelitian berdasarkan teori partisipasi dari segi bentuk ditemukan bahwa terdampak tiga bentuk partisipasi yaitu tenaga, pikiran dan materi, sedangkan respon keterlibatan mahasiswa dalam berorganisasi di Fakultas Ilmu Sosial adalah adanya kompetensi dalam diri mahasiswa, menambah pengalaman dalam organisasi, eksistensi diri, mengisi waktu luang dan memperluas jejaring pergaulan, serta adanya upaya dalam meningkatkan partisipasi mahasiswa dalam berorganisai di Fakultas Ilmu Sosial. Partisipasi mahasiswa dalam berorganisasi belum optimal sehingga diharapkan adanya pembaharuan dalam organisasi dan harus saling berkerjasama antar organisasi mahasiswa.

Kata Kunci: partisipasi, mahasiswa, organisasi

\section{ABSTRACT}

This research is motivated by the low participation of college students in following the organization at the faculty level. The purpose of this research is to describe the forms of participation, student engagement response and efforts to increase college student participation in organizing the Faculty of Social Sciences. This research uses qualitative methods of descriptive approach with research informant consisting of Deputy Dean III FIS UNP, Student organization leaders, chairman of BPM, Governor of BEM, chairman of HMJ ISP, chairman of HMJ Sociology, chairman of HMJ IAN, chairman of HMJ history, chairman HMJ Geography, chairman of HMJ Pendikais, and student of the Faculty of Social Sciences. Data collection methods in the form of observation, interviews and documentation. The results of the research based on the theory of participation in the form were found that affected three forms of participation namely energy, mind and matter, while the student involvement 
response in the organization of the Faculty of Social Sciences is a competency In students, adding experience in the organization, self-existence, filling free time and expanding social networking, as well as efforts to increase student participation in organizing at the Faculty of Social Sciences. The participation of students in the organization is not optimal so it is expected that there is renewal in the organization and must cooperate among college student organizations.

Keywords : participation, college student and organization

\section{PENDAHULUAN}

Perguruan tinggi merupakan sebuah lembaga pendidikan yang didalamnya terdapat sarana dan prasana yang berguna untuk menunjang terciptanya tujuan pendidikan. Perguruan tinggi memiliki kepengurusan organisasi yang biasa disebut dengan organisasi mahasiswa yang bertujuan untuk mengembangkan potensi serta bakat yang dimiliki oleh mahasiswa. Organisasi mahasiswa tersebut merupakan wadah yang digunakan dalam mengembangkan setiap kemampuan yang dimiliki oleh mahasiswa, sesuai dengan isi UndangUndang Nomor 12 tahun 2012 pasal 14 yang intinya bahwa mahasiswa tersebut harus mampu mengembangkan bakat, minat serta kemampuannya melalui ekstrakurikuler kampus yaitu organisasi mahasiswa. Universitas Negeri Padang merupakah salah satu perguruan tinggi dengan organisasi mahasiswa yang terdapat di tingkat universitas ataupun fakultas. Salah satunya yaitu Fakultas Ilmu Sosial Universitas Negeri Padang yang merupakan salah satu fakultas yang mahasiswanya cukup aktif di organisasi universitas, namun di organisasi fakultas partisipasi mahasiswanya rendah. Hal ini dibuktikan dengan data yang menyatakan bahwa hanya 10,15\% mahasiswa yang berpartisipasi dalam organisasi dari 8 organisasi mahasiswa yang ada di Fakultas Ilmu Sosial yaitu Badan Eksekutif Mahasiswa, Badan Perwakilah Mahasiswa, dan HMJ tiap jurusan yang terdiri dari 6 jurusan seperti ISP, IAN, Sosiologi, Sejarah, Geografi, IAI.

Davis dalam jurnal Salam (2010) menyatakan partisipasi dapat didefinisikan sebagai keterlibatan emosi dan pikiran seseorang dalam memberikan sumbangan ke dalam suatu kelompok guna mencapai suatu tujuan dengan tetap mempertanggungjawabkan segala usaha yang diberikan. Peran serta seseorang atau sekelompok orang dalam proses pembangunan berupa bentuk kegiatan dengan memberi masukan pikiran, tenaga, hingga materi (Desmawangga, 2013). Kesimpulannya bahwa partisipasi merupakan keterlibatan seseorang atau bahkan lebih guna mencapai tujuan bersama dengan cara bekerjasama.

Rendahnya partisipasi mahasiswa dalam berorganisasi akan berdampak terhadap kemampuannya di dunia kerja, karena berdasarkan 
survei NASA 2005 menyatakan bahwa komunikasi merupakan aspek utama yang diharapkan dalam dunia kerja. Oleh karena itu dengan berorganisasi diharapkan mahasiswa bisa mengembangkan kompetensi yang dimilikinya tersebut sehingga dapat dijadikan bekal untuk dunia kerja. Selain itu dengan berorganisasi mahasiswa juga akan belajar berpendapat, bekerjasama, berinteraksi, bertukar pikiran serta manfaat yang lainnya. Keterlibatan mahasiswa dalam berorganisasi merupakan cara untuk meningkatkan kemampuan diri sekaligus tempat untuk menambah ilmu tentang organisasi, namun tidak dapat dipungkiri juga bahwa tujuan mahasiswa untuk berpartisipasi dalam organisasi sangat berbeda-beda.

Dalam perkembangannya partisipasi mahasiswa berarti keterlibatan mahasiswa dalam suatu organisasi, hal tersebut dapat dilihat dari respon keterlibatan mahasiswa dalam mengikuti organisasi mahasiswa yang tidak hanya ditingkat universitas tetapi juga tingkat fakultas salah satunya di Fakultas Ilmu Sosial. (Masrukhi, 2016) menyatakan bahwa keberadaan organisasi kemahasiswaan serta dinamikanya dapat dijadikan oleh mahasiswa sebagai perpaduan interaksi mereka dikampus. Dalam wawancara awal yang telah dilakukan, peneliti menemukan beberapa permasalahan penting yaitu kurangnya pengetahuan mahasiswa mengenai organisasi berdampak pada rendahnya partisipasi mahasiswa yang mengakibatkan mahasiswa tidak mampu menjadi agent of change di dalam masyarakat serta kurangnya sosialisasi terkait organisasi mahasiswa yang dilakukan oleh organisasi yang ada di Fakultas Ilmu Sosial.

Berdasarkan penelitian dilapangan terkait partisipasi mahasiswa dalam berorganisasi ditemukan berbagai macam bentuk partisipasi mulari dari partisipasi pikiran, tenaga dan materi. Oleh sebab itu dengan adanya bentuk partisipasi tersebut maka dalam artikel ini dapat dideskripsikan mengenai respon keterlibatan mahasiswa dalam berorganisasi di Fakultas Ilmu Sosial.

\section{METODE PENELITIAN}

Metode penelitian yang digunakan adalah kualitatif dengan pendekatan deskriptif, hal ini dikarenakan melalui metode tersebut dapat tergambar secara detail permasalahan penelitian yakni partisipasi mahasiswa dalam berorganisasi (Sugiyono, 2017). Sementara informan penelitian terdiri dari Wakil Dekan III FIS UNP, Pembina Organisasi Mahasiswa, ketua BPM, Gubernur BEM, Ketua HMJ ISP, ketua HMJ Sosiologi, Ketua HMJ IAN, Ketua HMJ Sejarah, Ketua HMJ Geografi, Ketua HMJ Pendikais, dan mahasiswa yang dipilih secara purposive sampling yaitu dipilih karena orang-orang tersebut memahami terkait permasalahan penelitian (Ahmadi, 2014). Pengumpulan data dilakukan dengan wawancara, observasi dan dokumentasi. Uji keabsahan data dengan menggunakan Teknik triangulasi data. Teknik analisis data dilakukan dengan tahapan pengumpulan data, reduksi data, penyejian data dan mengambil kesimpulan atau verifikasi data (Sugiyono, 2017). 


\section{HASIL DAN PEMBAHASAN}

\section{Respon Keterlibatan Mahasiswa dalam Berorganisasi di Fakultas Ilmu sosial Universitas Negeri Padang}

Keterlibatan mahasiswa dalam berorganisasi merupakan keikutsertaan mahasiswa dalam suatu organisasi baik itu berupa hal positif maupun negatif. Berdasakan hasil penelitian dilapangan didapatkan bahwa ada lima keterlibatan mahasiswa dalam berorganisasi diantaranya adalah

\section{Menambah Pengalaman dalam Organisasi}

Berdasarkan hasil penelitian dilapangan bahwa respon keterlibatan mahasiswa dalam berorganisasi di fakultas adalah dengan berorganisasi secara tidak langsung mahasiswa akan menambah pengalaman pribadinya terutama dibidang organisasi. Pengalaman dalam bidang organisasi tersebut meliputi cara mengatur kegiatan y atau program kerja, belajar untuk memimpin, belajar berkomunikasi hingga belajar untuk saling menyampaikan pendapat dalam kelompok organisasi mahasiswa. Berdasarkan temuan di lapangan, peneliti menyimpulkan bahwa dengan bertambahnya pengalaman mahasiswa dalam organisasi hal tersebut dapat mendukung untuk aspek yang lainnya seperti kepemimpinan, komunikasi hingga cara menyampaikan pendapat.

\section{Eksistensi Diri}

Eksistensi atau keterkenalan diri seseorang dalam berorganisasi merupakan salah satu respon keterlibatan mahasiswa yang lain. Hal ini berkaitan dengan cara mahasiswa itu sendiri agar mahasiswa tersebut dapat dikenal oleh masyarakat kampus seperti teman sebaya, senior dan juga dosen. Proses eksistensi diri berdekatan dnegan aktualisasi diri. aktualisasi diri yang sudah berjalan dengan baik dapat membentuk ketahanan pribadi pemuda yang tangguh dan baik seacara mental (Hamdi, Supraja, Zubaidi, 2016).

Berdasarkan hasil penelitian dilapangan eksistensi diri juga berkaitan dengan cara mahasiswa untuk mengembangkan dan menggali potensi yang ada dalam diri mahasiswa itu sendiri.

Adapun dalam aspek ini dapat diketahui bahwa keterlibatan mahasiswa dengan memberikan respon mengenai eksistensi diri dapat ditarik kesimpulan bahwa keterkenalan mereka didunia kampus tidak hanya untuk mencari kesenangan belaka namun juga menggali potensi hingga menambah lingkup pertemanan yang tidak hanya dikampus tetapi juga luar kampus, karena kita tau bahwa dikalangan mahasiswa eksistensi diri diartikan dengan hal negatif salah satunya seperti unjuk diri.

\section{Kurang Mengerti dengan Manfaat Organisasi}

Kebanyakan mahasiswa ketika memberikan respon mengenai keterlibatan mahasiswa dalam berorganisasi ada yang negative salah satunya yaitu mahasiswa yang kurang mengerti manfaat organisasi. Berdasarkan temuan di lapangan dapat diketahui bahwa mahasiswa tidak ikut terlibat atau tidak ikut serta dalam organisasi mahasiswa di fakultas karena mereka merasa ikut atau tidaknya dalam organisasi hal tersebut tidak akan memberikan pengaruh kepada nilai mereka selama kuliah dan juga sukses atau tidaknya 
mereka tidak bergantung kepada keterlibatan mereka dalam organisasi

Adapun respon keterlibatan mahasiswa yang satu ini dapat disimpulkan bahwa tidak selamanya respon mahasiswa positif mereka terkadang tidak ingin berpartisipasi diakarenakan berbagai macam aspek salah satunya yaitu kurang mengerti dengan manfaat organisasi mahasiswa itu sendiri, sehingga diharapkan mahasiswa harus lebih mempelajari hal tersebut dan tidak mengesampingkan mengenai manfaat organisasi.

\section{Mengisi Waktu Jenuh Selam Kuliah}

Respon keterlibatan mahasiswa yang lainnya mengenai organisasi mahasiswa di fakultas adalah untuk mengisi waktu mahasiswa tersebut selama kuliah. Berdasarkan temuan dilapangan dapat diketahui bahwa mengisi waktu selama kuliah yang dimaksudkan oleh mahasiswa adalah ketika mereka merasa jenuh dan bosan selama perkuliahan mereka lebih memilih untuk meninggalkan jam kuliah dan menjadikan organisasi sebagai tempat pelarian mereka untuk mengatasi hal tersebut.

Adapun aspek ini berkaitan dengan hal negatif Karena mahasiswa rela meninggalkan kuliah demi berorganisasi, karena berdasarkan temuan tersebut mahasiswa berpikir jenuh selama jam kuliah dapat dihilangkan dengan berkumpul, bercerita dan mencari kesenangan belaka melalui organisasi dan juga organisasi memiliki ruang sendiri yang bisa mereka gunakan untuk beristirah sehingga terkadang banyak dosen yang menyalahkan mahasiswa yang izin karena kegiatan organisasi.

Menggangu Perkuliahan
Dalam hal ini respon keterlibatan mahasiswa yang terakhir yaitu menggangu perkuliahan mahasiswa itu sendiri, maksudnya adalah bahwa mahasiswa beranggapan dengan ikut serta dalam organisasi maka hal tersebut akan mengganggu jalannya perkuliahan mereka seperti pulang kuliah mereka harus rapat,ketika kuliah mereka harus rela meninggalkan kuliah untuk kepentingan organisasi, serta dengan kesibukan dalam organisasi akan mengancam nilai akhir mereka selama kuliah. Sehingga dari hal tersebut dapat ditarik kesimpulan bahwa berpartisipasi atau ikut terlibat dalam organisasi akan membagi fokus mereka selama kuliah, oleh sebab itu sebagian mahasiswa memilih untuk memfokuskan diri menjalani perkuliahan.

\section{KESIMPULAN}

Partisipasi mahasiswa dalam organisasi mahasiswa adalah bentuk keaktifan mahasiswa dalam memberikan ide, gagasan, tenaga, materi, dan kerjasama dalam pelaksanaan suatu kegiatan organisasi mahasiswa. Berdasarkan temuan peneliti dapat disimpulkan bahwa bentuk partisipasi mahasiswa dalam berorganisasi adalah partisipasi pikiran, partisipasi tenaga dan partisipasi materi. Sedangkan respon keterlibatan mahasiswa terkait dengan organisasi mahasiswa yang ada di Fakultas Ilmu Sosial adalah meningkatkan kompetensi dalam diri mahasiswa, menambah pengalaman dalam organisasi, eksistensi diri, mengisi waktu luang dan memperluas jejaring pergaulan. Kurang mengerti dengan manfaat organisasi serta mengganggu perkuliahan. Implikasi penulisan artikel ini terhadap 
penelitian lainnya adalah dapat membantu penelitian dalam memahami latarbelakang partisipasi mahasiswa dalam berorganisasi dilihat dari segi bentuk partisipasi, respon keterlibatan mahasiswa hingga adanya upaya yang dilakukan untuk meningkatkan partisipasi mahasiswa dalam berorganisasi di Fakultas Ilmu Sosial Universitas Negeri Padang. Implikasi penulisan artikel ini terhadap penelitian lainnya adalah dapat membantu penelitian dalam memahami apa sebenarnya yang melatarbelakangi partisipasi mahasiswa dalam berorganisasi dilihat dari bentuk partisipasi mahasiswa tersebut, serta penelitian ini memberikan bantuan kepada peneliti lain mengenai respon keterlibatan mahasiswa dalam berorganisasi.

\section{DAFTAR PUSTAKA}

Ahmadi, Rulam 2014. Metodologi Penelitian Kualitatif. Yogyakarta: Ar-Ruzz Media

Desmawangga, C. (2013). Studi Tentang Partisipasi Mahasiswa Program Studi Administrasi Negara Dalam Organisasi Kemahasiswaan Di Fakultas Ilmu Sosial Dan Ilmu Politik Universitas Mulawarman. EJournal: llmu Administrasi, 1(2), 683-697.

Masrukhi, (2016),

Pengembangan

Strategi

Kemahasiswaan.

Organisasi

Jurnal

Didaktika Islamika. 7(1): 1-16

Salam, M. R. (2010). Partisipasi Masyarakat Dalam Peningkatan Kualitas Permukiman Dikawasan Pusat Kota Palu. JURNAL ARSITEKTUR, 2(2).
Sugiyono. (2017). Metode Penelitian kualitatif, kuantitatif dan RED. Bandung: Alfabeta.

Hamdi, I., Supraja, M., \& Zubaidi, A. (2016). Dinamika Aktualisasi Diri Pemuda Rantau Dan Implikasinya Terhadap Ketahanan Pribadi (Studi Pada Mahasiswa Rantau Asal Sumatera Barat Di Asrama Putri Bundo Kanduang Daerah Istimewa Yogyakarta). Jurnal Ketahanan Nasional, 22(3), 306320. 